\title{
A Kárpát-csoport repülőcsoportja 1941. nyári-őszi harcaiból levont tapasztalatok
}

K assa - felségjelek nélküli repülőgépekkel végrehajtott -, 1941. június 26-i (alapvetően nem katonai célpontok elleni) bombázását ${ }^{1}$ casus belliként felhasználva, másnap 10 óra 30 perckor Bárdossy László miniszterelnök és külügyminiszter a Parlamentben felszólalt: „Egészen rövid bejelentést szeretnék tenni... Magyarország és a Szovjetunió között a hadiállapot beállott."2 Egyben, megfelelő megtorló intézkedéseket is kilátásba helyezett, nem zavartatván attól a ténytől, hogy már 08:00kor egy Junkers Ju 86 és Caproni Ca-135 típusokból álló, „összevont bombázórepülö-század”3 - egy vadászszázad oltalmazása mellett - csapást mért Sztanyiszlávra, majd 29-én Sztríre.

Sztanyiszláv bombázásával egyidőben, a VIII. és X. közelfelderítő századok nyolc, illetve kilenc WM-21 Sólyom típusú repülőgépe támadta a határ menti szovjet településeket. A fentiek alapján a sajtó lelkesen ünnepelt: „A magyar légierő a ma reggeli órákban igen eredményes megtorló támadásokat hajtott végre Szovjet-orosz területe-

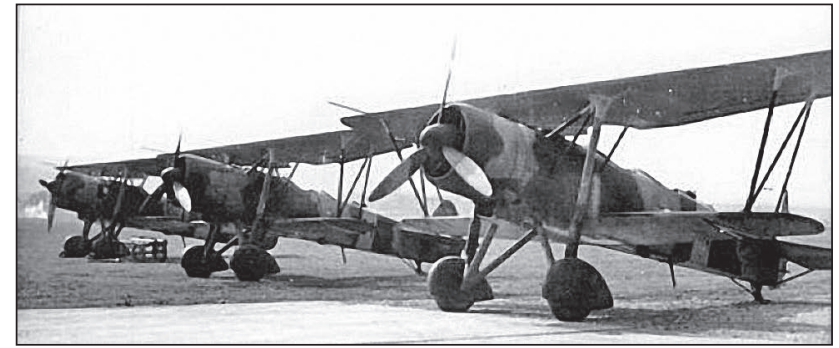

2. ábra. WM-21 Sólyom közelfelderítő repülögép ${ }^{7}$

ken lévő katonai célpontok ellen". 5 A repülőszakember azonban azt tartotta fontosabbnak, hogy először repültek át bombázókötelékek műszerek segítségével a Kárpátok fölött és tértek vissza veszteség nélkül. ${ }^{6}$

Szombathelyi Ferenc altábornagy, a kassai VIII. hadtest parancsnokának vezetésével június 30-ra vált működőképessé a Szovjetunió ellen bevetendő Kárpát-csoport, állo-

1. ábra. Junkers Ju 86 és Caproni Ca-135-ös bombázó-repülögépek ${ }^{4}$

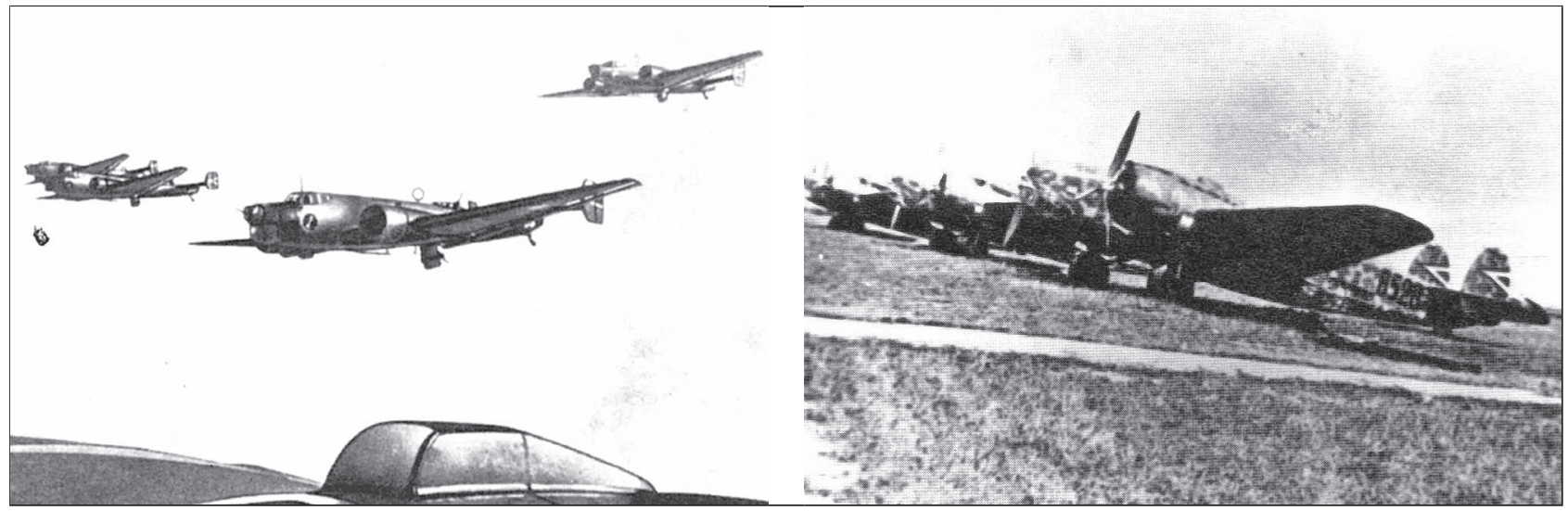

ÖSSZEFOGLALÁS: A trianoni békediktátum 1938. augusztusi lezárását követően, az 1939. január 1-jétôl önálló magyar légierő számára az első igazi harci tapasztalatszerzést az 1941. nyári-őszi ukrajnai hadmúvelet jelentette. A Kárpát-csoport harcát támogató repülő́csoport először került tartósan harci viszonyok közé. A légierő vezérkara a szerzett tapasztalatokat folyamatosan feldolgozta és alkalmazta. A légierő parancsnoka ezek alapján, 1942 elején alapos „kiértékelést” készített mind a harcászati, mind a harcászati-technikai tapasztalatok általánosítása terén, amit felterjesztett a honvédelmi miniszterhez és a Honvéd Vezérkar fönökéhez további hasznosításra.

KULCSSZAVAK: repülőcsoport, alegységek rotálása, gyalogsági harc, típuscserék, harci tapasztalatok
ABSTRACT: Shortly after the closure of the 1938 August Trianon dictation of peace, the Hungarian Air Force - which became to be independent as from January 11939 - could gaine the first real combat experience in the 1941 summer-autumn operations in The Ukraine. That was the first time, that the air-group - supported the operation of the "Karpat-group" - found itself in combat conditions. The Air Force Chief of Staff continuously elaborated and applied the combat experience gained. However the Air Force Commander upon these - made an accurate evaluation in the first part of 1942, including all the tactical, and the tactical-technical aspect, which he introduced to the Minister of Home Defence and to the Defence Chief of Army Staff.

KEY WORDS: air-group, rotation of subunits, infantry fight, type-rotations, combat experience

NKE professor emeritus, a Magyar Tudományos Akadémia rendes tagja. ORCID: 0000-0003-3183-1774 
mányában az I. gyorshadtesttel, az I. hegyi és a 8. határvadászdandárral, akiknek a harcát egy repülőcsoport támogatta Orosz Béla alezredes parancsnoksága alatt.

A Kárpát-csoport július 1-jén lendült támadásba a Tatárhágón és az Uzsoki-szoroson át Kolomija, valamint Sztanyiszláv irányába, a közelfelderítők, illetve a bombázók támogatása mellett.

Az ukrán síkságra kijutva, a hegyi és a határvadász erők visszamaradtak megszállási feladatokkal, míg a gyorshadtest, továbbá repülőcsoportja igyekeztek mihamarabb kijutni a Dnyeszterhez, majd tovább, a Dnyeperig.

A légierő vezérkara mindent megtett egyrészt azért, hogy a folyamatos támogatás érdekében, illetve a Kárpátok fölötti gyakori átrepülések veszélyeinek csökkentésére mihamarabb ukrán repülőterekre telepítse át kötelékeit, másrészt folyamatos rotációkkal, minél több távol- és közelfelderítő, vadász-, továbbá bombázó-alegységnek biztosítson háborús tapasztalatszerzési lehetőséget. (Ez utóbbinak megfelelően, július és november között négy bombázó-, öt közelfelderítő, valamint négy vadászszázad kapott lehetőséget harci alkalmazásra.)

Tekintettel arra, hogy az 1941. július 15-én beérkezett, az olaszoktól vásárolt 47 db Reggiane Re-2000 Falco I. vadászgépekkel több probléma is felmerült, illetve a gyártási licencét is megvették, a típus tökéletesítése érdekében egy hétrepülőgépes ún. „kísérleti rajt” küldtek ki hadműveleti területre egy hónapos tapasztalatszerzésre. Így, jelentősen javíthatták az ezek figyelembevételével is tökéletesített magyar Héják képességeit.

Július-augusztus folyamán a repülőalegységek szinte napról napra váltva repülőtereket, egyre közelebb jutottak a Dnyeper vonaláig. Így, pl. az 1/3. vadászrepülő-század augusztus 19-én már Krivoj Rog repülőterére települt.

Augusztus 28-án Gyiresy Sándor rep. alezredes váltotta Orosz alezredest a repülőcsoport élén.

A fokozatosan beköszönő ukrán ősz a sok esőjével, sártengerré váló repülőtereivel egyre nehezebbé tette a repülőalegységek alkalmazását, így fokozatosan - november 26-i befejezéssel - hazatelepültek.

Ez alatt az öt hónap alatt a repülőcsoport repülőgépei 1454 harci bevetés során 2192 órát töltöttek a levegőben, $217 \mathrm{t}$ bombát dobtak le és 30 szovjet repülőgépet semmisítettek meg. Ezzel szemben el kellett könyvelniük 17 tiszt és 15 legénységi állományú repülős katona elvesztését; négy tiszt, valamint két legénységi honvéd eltűnését, továbbá 10 tiszt és 18 legénységi állományú katona megsebesülését. Ami a harceszközöket illette: a 25 felderítő-, 14 vadász-, 11 bombázó-, öt futár- és egy szállító-repülőgépből 21 eltűnt, vagy szenvedett 100\%-os rongálódást, míg a többi $20-90 \%-$ os sérülést. ${ }^{9}$

Mint korábban láthattuk, a légierő vezetése maximálisan törekedett a háborús tapasztalatok minél nagyobb mérvú

3. ábra. Reggiane Re-2000 Falco I. vadászrepülőgép ${ }^{8}$ a képen olasz felségjellel

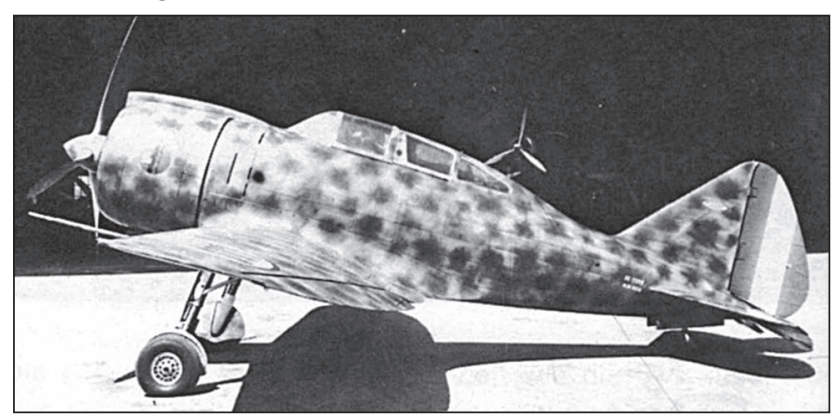

begyűjtésére, többel kapcsolatban intézkedések is születtek, de az alapos, átfogó következtetések levonáshoz szükség volt néhány hétre. $\mathrm{E}$ vonatkozásban két iratról feltétlenül szólni kell.

Az egyik, a légierő parancsnokság által 1941 késő őszén kiadott $-s$ alig egy év múlva „történelmi jelentőségűvé” nemesülő ${ }^{10}$ - „Intézkedés a légierő továbbképzésére és gyakorlatbantartására"11 (sic!), ami mind a szovjet repülők harceljárását, mind a Kárpátok fölötti katasztrófák ${ }^{12}$ tanulságait figyelembe vette. E szerint, „A továbbképzés célja a légierő egységeinek és kötelékeinek harcértékét és ütőképességét a legmagasabb fokra emelni... A gyakorlatban tartással pedig azt kell elérnünk, hogy a kiképzési év bármely szakában, tehát bármikor, magas harcértékkel készen álljunk bevetésre."

Ennek szellemében, a repülőkiképzés a repülőosztály parancsnokának a feladata, amit úgy kell megszerveznie, hogy „A súly a hajózó- és földi rész kiképzésének súrlódásmentes végrehajtásán nyugodjék."

A repülőminősítések kiértékelése során megállapítást nyert, miszerint „... a legnagyobb kiképzési hiány az éjjeli és müszerrepülés, valamint a lövésszaki kiképzési ágban áll fenn ezért elsősorban ezeknek a hiányoknak az eltüntetésére kell súlyt helyezni". Ezzel összefüggésben a kiképzési osztály vezetője reményét fejezte ki, hogy az éjjeli és műszerrepülés oktatására alkalmas repülőgépek még a folyó évben nagyobb számban állnak majd rendelkezésre. Ezen túl, addig sem tétlenkedve előírták, hogy „A repülőgépek beérkezéséig is súlyképzéssel, tanfolyamokon fog történni a vakrepülő kiképzés hiányainak pótlása. A bombavető és a rep. lőkiképzésnél mutatkozó jelentékeny hiányok kiküszöbölését a bombázó- és lőterek megfelelő számú biztositásával és külön rep. lőiskola felállitásával kivánom előmozdítani." - rögzítette Balássy rep. vk. őrnagy. (Eredeti helyesírással - Sz. M.)

Balássy Miklós - fent jelzett - „történelmi előrelátását", sok repülőtársa életének a megmentését mégis az a mondata fémjelzi, amely szerint „A gyalogsági harc-és lőkiképzésre az eddiginél lényegesen nagyobb súlyt kell helyezni". Ennek megfelelően, havonta egyszer félnapos földi harcgyakorlat keretében kellett sulykolni olyan harcmozzanatokat, amelyek háborús viszonyok között adódhatnak: repülőtér védelme, ellenséges harckocsik és ej-

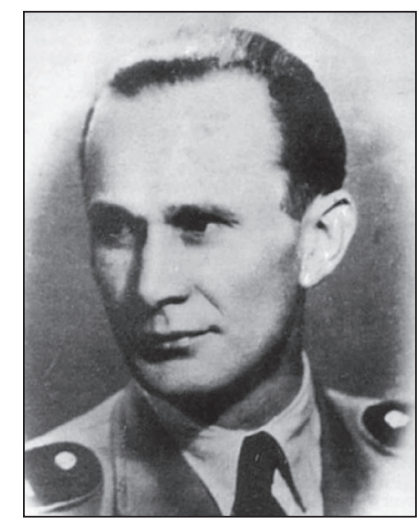

4. ábra. Balássy Miklós ${ }^{13}$ tőernyősök elleni harc, a földi rész menetének biztosítása stb. (Mint fent jeleztem, ez az intézkedés óriási felháborodást váltott ki a légierő állományában, de az 1943. januári események teljes mértékben igazolták - Sz. M.)

A másik nagyon fontos okmány, a „Haditapasztalatok kiértékelése", ${ }^{14}$ amit Rákosi Béla altábornagy, a légierő parancsnoka terjesztett fel a vezérkarfőnökhöz 1942. február 11-én.

$A z$ első részben a honvédelmi miniszteri és vezérkarfőnöki döntéseket igénylő tapasztalatokat szedték csokorba. Így:

1. A vezetési szervek működése, harcvezetése témakörben:

- a repülőgépek korszerűtlenek, ezért a légierő alkalmazása majdnem kizárólag harcászati feladatok végre- 
hajtásában merült ki, illetve a földi csapatok közvetlen támogatására szorítkozott;

- az I. gyorshadtest repülőparancsnokának szervezete, jog- és hatásköre részleteiben nem volt szabályozva, ami súrlódásokhoz vezetett. Ezért a jövőben, amenynyiben ismét hasonló repülőcsoport vezetése kerül napirendre, ebben az esetben repülőparancsnoki törzsként csökkentett állományú seregtest-parancsnoksági (dandár-) törzset szükséges alkalmazni;

- a vezetést megnehezítette, hogy a repülőcsoport-parancsnokság és a müködő repülőcsapatok között nagy volt a távolság, így a kiadott parancsokat rejtjelezni kellett, ami viszont a korszerűtlen rejtjelző gépek miatt rendkívül hosszadalmas volt. Ezért szükséges gyorsabban működő, könnyebben kezelhető eszközök rendszeresítése.

2. Az összeköttetés terén:

- nem rendelkeztek vezetékes eszközökkel, illetve

- a vadászrepülőgépeken nincs rádió, ezért ezek sürgős beszerelése szükséges.

3. A parancsnokságok, csapatok szervezete, létszáma:

- a földi alakulatoknál szükséges rendszeresíteni repülő-összekötő tiszti beosztást;

- a szakemberhiányt fokozta, hogy sok kiképzett szakszemélyzetet a hadiüzemek kérésére felmentettek;

- a hajózószemélyzetet már békében hadiállományban kell tartani, mert a tartalékosok utánképzése, gyakorlatban tartása nem megfelelő.

4. Rendszeresített anyagok:

- a repülőcsoport-parancsnoksághoz egy szállítórepülö-rajt kell rendszeresíteni;

- a repülőcsoport- és a hadtest repülő-parancsnokságokon két-két; a repülőezred-, -osztály- és -századparancsnokságokon egy-egy Fieseler Fi 156 Storch, valamint minden hadtest repülö-parancsnokságon egy-egy Focke-Wulf Fw 58 futárrepülőgép rendszeresítendő;

- a WM-21 Sólyom közelfelderítő repülőgép rövid repülési idővel, kis működési sugárral és sebességgel, valamint igen rossz repülési tulajdonsággal rendelkezik, ezért háborús feladatok ellátására alkalmatlan,

5. ábra. Fieseler Fi 156 Storch finn felségjellel és Focke-Wulf Fw 58 Weihe futárrepülögép magyar felségjellel ${ }^{15}$

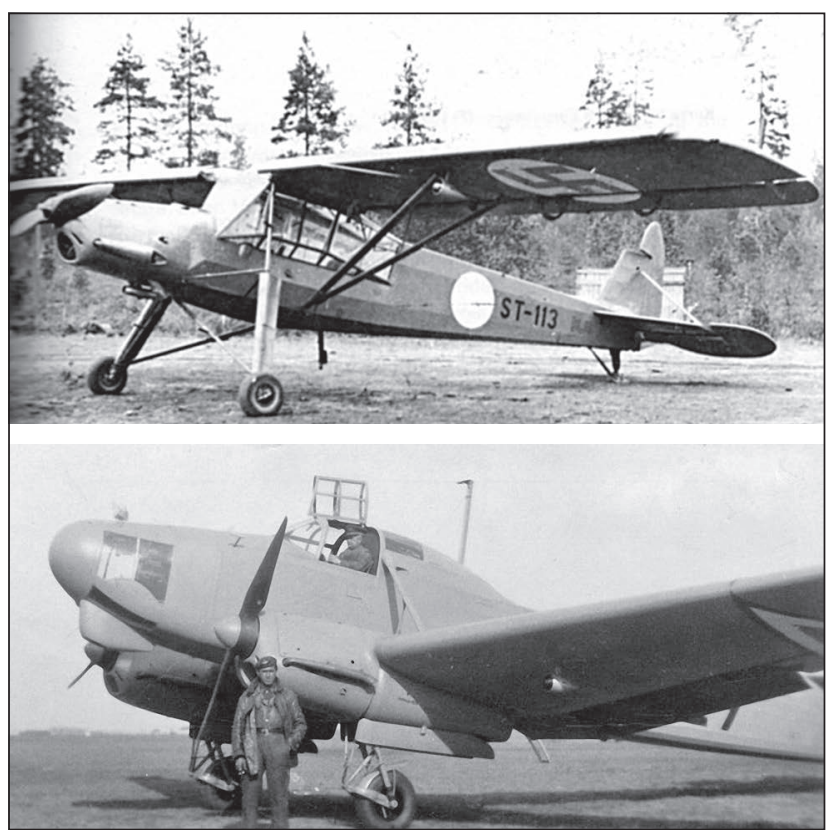

ezek miatt veszített a III. közelfelderítő század öt halottat és három repülőgépet. Ezért javasolja a légierő parancsnoka, hogy amíg nem biztosítható megfelelő repülőgéptípus, addig a mozgósítás elrendelésekor a meglévő Heinkel He 46-osokat alkalmazzák, de ezt is előzze meg alkalmassági és üzemképességi felülvizsgálatuk. (A jelentés nem foglalkozott a Heinkel He 70 távolfelderítő repülőgéppel, mert a század viszonylag gyorsan elveszítette gépállományát, így 1941 második felében érdemben már nem tevékenykedett, hanem készült a He 111 típus fogadására - Sz. M.);

- a Caproni Ca-135-ös bombázó-repülőgépek még a „csökkentett kívánalmaknak is csak szükségképpen” feleltek meg, ezért ki kell vonni az I. vonalbeli harci repülőgépek sorából;

- csak fémszerkezetű repülőgépeket szabad a jövőben rendszeresíteni, tekintettel a szabadban való tárolásukra, valamint a légi harcban való gyúlékonyságra;

- a repülőgépek legérzékenyebb részeit (pilótaülés, üzemanyagtartály) páncélozni kell, illetve a szélvédőket és az ablakokat cseréljék ki ún. páncélüvegekre;

- a Breda-géppuskák alapvetően jól működtek, csak a lőszerhevederek „megnyúlása” okozott sok gondot. Emellett - mivel „a szovjet vadászok részben gá-val (gépágyúval - Sz. M.) is fel voltak szerelve" -, javasolták hasonlóak rendszeresítését a magyar vadászrepülőgépeken is;

- a közelközelfelderítő századoknál rendszeresített R/11 és $\mathrm{R} / 11 \mathrm{a}$ rádiókészülékek bonyolultak, nem üzembiztosak.

5. Erkölcsi tényezők:

- az otthonról kapott levelek tele vannak panasszal, valamint

- az is feszültséget indukált, hogy a német katonák magasabb zsoldot és jobb ellátást kapnak.

6. Együttműködés a földi csapatokkal:

- a „békeidőkből” nincs megfelelő tapasztalat;

- a földi csapatok - megfelelő eszközök hiányában nem jelezték első vonalukat;

- a szárazföldi erők érdekében végzett felderítési adatokat - ledobóhelyek hiányában - csak a leszállás után adhatták ki;

- késve igényeltek légi támogatást.

7. Harci tapasztalatok:

- az I-16 Rata vadászrepülőgép a FIAT Cr-42-esnél gyorsabb, így gyorsan kivonhatja magát a légi harcból, viszont a Cr-42 kiváló fordulékonyságú. (A jelentés nem említette, de a pilóták visszaemlékezéseiben annál gyakrabban szerepelt az az ,irigykedő” mondat, hogy: „Erős páncél van a gép alján és a pilóta mögött is." - Sz. M.) Ugyanakkor - más vonatkozásban - a jelentés szintén foglalkozott ezzel a kérdéssel: ez az erős páncélozottság tette lehetővé, hogy sokszor 15-20 gépes kötelékekben, alacsonyan támadják a magyar csapatok éleit, anélkül, hogy veszteségeket szenvedtek volna a földi elhárító tűztől;

- a Reggiane Re-2000 Falco-1 (az iratban már „megelőlegezték” a majdani magyar gyártmányúak Héja elnevezését - Sz. M.) kísérleti raj megítélése pozitív volt: „A típus hadialkalmazásra jól bevált. A hdm-ek (hadműveletek - Sz. M.) alatt ki lett próbálva mindazon alkalmazásban, melynek végrehajtása a vadászkötelékek feladata. A kapott feladatokat minden egyes esetben igen jó eredménnyel oldotta meg. Ehhez hozzájárult a típus korszerű sebessége, igen jó fordulékonysága és jó emelkedőképessége." következtében. 


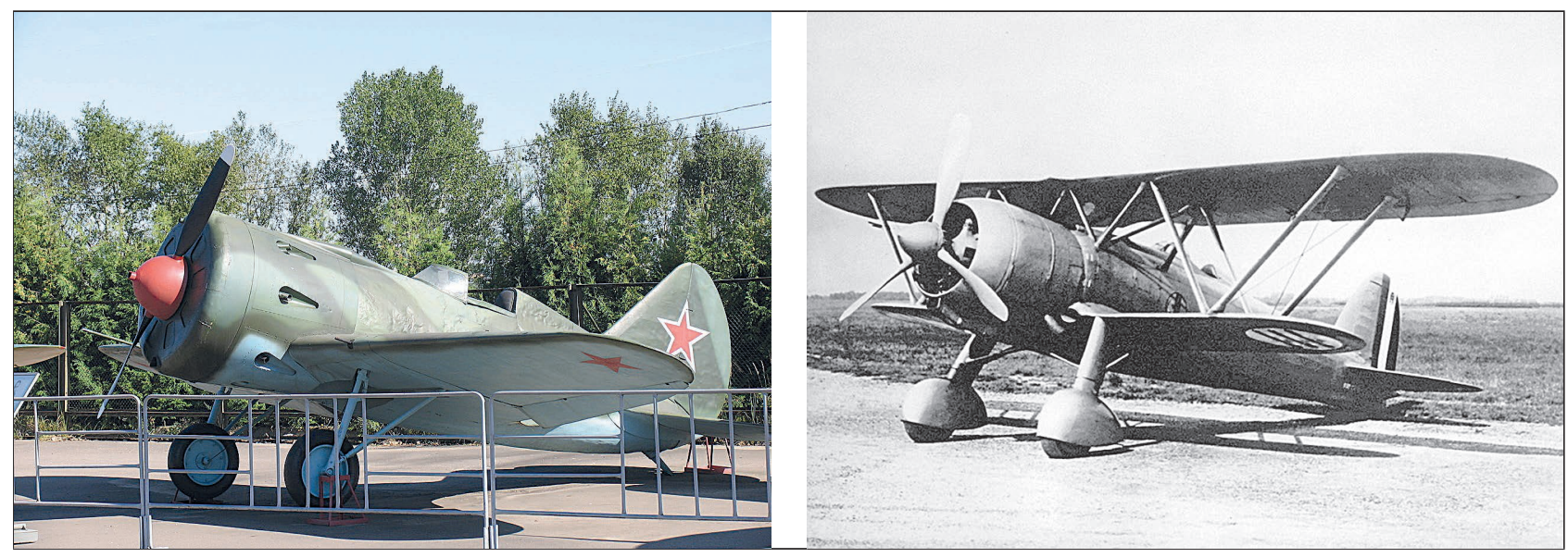

6. ábra. I-16 Rata szovjet és a Magyar Királyi Légieröben is alkalmazott FIAT Cr-42 vadászrepülögép ${ }^{16}$

Mint látható, a Légierő Parancsnokság gyors és alapos „kiértékeléssel” igyekezett megfelelő alapokat teremteni a további harcok jobb feltételeinek biztosítása érdekében. Ebben a Vezérkar 1. (hadmúveleti) osztály is partner volt, mivel véleményében - egyebek mellet - rögzítette, hogy a hajózószemélyzetnek már békében hadi állományra feltöltésére vonatkozó javaslat olyan elvi jelentőséggel bír, hogy a vezérkarfőnök hasonló értelmű döntése után az 1942/43. szervezési évre vonatkozó vezérkarfőnöki követelmények közé felveszi.

\footnotetext{
JeGYZETEK

1 Az első, hivatalos jelentést, ami nagyon korrektül „,ismeretlen felségjelű” repülőgépekről szólt, a háborús propaganda órákon belül átváltoztatta szovjet orvtámadásra, majd az ezt követő évtizedekben sorra jelentek meg a „szlovák”, a „német-magyar”, illetve a „román verziók” - politikaiideológiai „megrendelésre”, amelyek mindegyike tartalmazott érdekes adalékokat, de egyik sem volt képes egyértelmüen bizonyítani az elkövetők kilétét;

2 Dr. Ölvedi Ignác, Dr. Száva Péter. A második világháború képei I. kötet, 2. átd. kiad., 153. p. Bp.: Európa Könyvkiadó, 1975;

3 A veszprémi 4/II. bombázórepülö-osztály 16 db Junkers Ju 86 K-2 és a debreceni 3/5. bombázószázad 8 db Caproni Ca-135-ös repülőgépe. Az egyik kísérő vadászpilóta visszaemlékezése szerint: „Mi csodálkoztunk, honnan szedtek össze ennyit.” (Nyemecz Pál rep. zls. nyilatkozata - a szerző birtokában.)

4 M. Szabó Miklós: A Magyar Királyi Honvéd Légierő 1938-1945. Bp.: Zrínyi Kiadó, 1999. 302. és 301. p.;

5 Hadtörténelmi Levéltár Vezérkarfönökség Elnöki (HL Vkf. Eln.) 1941/5612;

6 Orosz Béla: A magyar légierők teljesítményei a Kárpátoktól a Dnyeperig (Hadinapló), Budapest: A Vitézi rend Zrínyi csoportja, 1942. 7. p.;

$7 \mathrm{https} / / / \mathrm{www}$.google.com/search?q=WM-21+S\%C3\%B3lyom\&tbm=isch\&source= iu\&ictx= 1\& fir= VIFY8I8q8X1x9M\%253A\%252C5wOdeTe9nm6vM\%252C_\&vet=1\&usg=AI4_-kR3loVgy CrTg T6UUA7SO_Jj0dv8SQ\&sa=X\&ved=2ahUKEwiuh9bkzNfjAhWItlsKHatOAMoQ9QEwAnoECAUQ CQ\#imgrc=ngLIFzOiKTxNiM:\&vet $=1$;

8 Munson, Kenneth: Die Weltkrieg II - Flugzauge. Stuttgart: Motorbuch Verlag,1972, 366. p.;

9 HL Vkf. Eln. 1. - 1942/4338 C. rész;

10 Mint látni fogjuk, az intézkedésben gyalogsági kiképzést is elrendeltek a hajózóállomány számára, ami hatalmas felzúdulást váltott ki az érintettekben. Így vált a légierő vezérkar kiképzési osztályvezetője, Balássy Miklós rep. vk. őrnagy a légierő legnépszerűtlenebb tisztjévé. Ez a kellemetlen „státusz" 1943. január második feléig „élt”, amikor is a szovjet harckocsierők uriv-scsucsjei hídfőkből indított hatalmas bekerítő hadmúvelete során repülökatonáknak kellett védeniük nagy páncéloskötelékekkel szemben az alekszejevkai repülőteret. Elkeseredett harc után - amikor már tarthatatlanná vált a helyzetük - kitörtek, majd megint bekerítésben harcoltak, ismét kitörtek, s ismétlődött ez mindaddig, míg nem csatlakozhattak a főerőkhöz. Ennek ellenére, a repülődandár vesztesége 1943. januárban „mindössze” 36 halott, 46 eltünt, 7 beteg, 56 sebesült és 32 fagysérült volt. Ekkor jöttek rá sokan, mit köszönhetnek Balássy rep. vk. örgy-nak:

11 HL Repülö Alakulatok (RA) 37. doboz (d.) 63100/eln. Le. I. - 1941;

12 A vakrepülésre többségében kiképzetlen állomány a - többségében - vakrepülőműszerek nélküli repülőgépekkel több esetben ütköztek felhőben, rossz látási viszonyok között a Kárpátok magasabb csúcsainak;

13 Kanadai Magyar Szárnyak archívuma;

14 HL Honvédelmi Minisztérium (HM) Eln. Vkf-1. 1942/4338;

15 Munson, Kenneth: A II. világháború repülögépei. Műszaki Könyvkiadó, Budapest 1994 99. o., valamint

http://www.repulomuzeum.hu/Adomanyok/HidvegiZoltan/HZ 2/HidvegiZoltan_2.htm

16 https://en.wikipedia.org/wiki/Polikarpov_I-16, valamint https://en.wikipedia.org/wiki/Fiat_CR.42
}

\title{
Olvasóink figyelmébe!
}

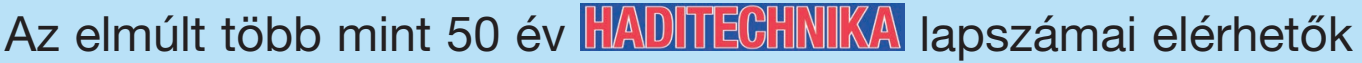 \\ a Magyar Tudományos Akadémia REAL-J repozitóriumában: \\ http://real-j.mtak.hu/view/journal/Haditechnika.html
}

